\title{
Relevance of Indigenous Conflict Management Mechanisms: Evidence from Bunkpurugu-Yunyoo and Central Gonja Districts of Northern Region, Ghana
}

\author{
Mohammed Gadafi Ibrahim \\ (Corresponding author) \\ School for Development Studies, College of Humanities and Legal \\ Studies, University of Cape Coast, Cape Coast, Ghana \\ Email: chiefgandaf@gmail.com \\ Joseph Kingley Adjei \\ Department of Sociology and Anthropology, College of Humanities and \\ Legal Studies, University of Cape Coast, Cape Coast, Ghana \\ Joseph Agyanim Boateng \\ School for Development Studies, College of Humanities and Legal \\ Studies, University of Cape Coast, Cape Coast, Ghana \\ DOI//http://dx.doi.org/10.4314/gjds.v16i1.2
}

\begin{abstract}
The Northern Region is witnessing protracted and relapsed conflicts, and attempts at resolving these largely through Western models, particularly the formal court system have not been successful. As such, this study explores the relevance of indigenous conflict management mechanisms in restoring enduring peace in the Northern Region of Ghana. The study employed a multiple case study design. Data was collected from fortythree purposively selected respondents using interviews, focus group discussions, and observations. The results from thematic and cross-site analysis revealed that indigenous mechanisms have features of inclusive participatory approach at all levels of the conflict leading to acceptable outcomes. The traditional mechanisms have proven to be immediate and meaningful, accessible, and affordable. The use of local languages is well understood by all parties and processes and procedure are well attuned to local needs as they produce quick justice for the people. The development of a comprehensive programme to incorporate aspects of both the indigenous and western-centred judicial structures for the purposes of legitimacy of management outcomes is proposed.
\end{abstract}


Keywords: Conflicts, Indigenous, Management, Mechanisms, Participatory, Ghana

\section{INTRODUCTION}

Conflicts date back to the beginning of human history (Sarpong-Anane, 2014). For as long as people, groups, and nations pursue conflicting interests, there will always be disagreements, disputes and conflicts (Otite, 1999). Thus, conflict is inescapable, inherent, and inevitable in social existence and social progress (Onwuzuruigbo, 2011). The results of conflicts are not predetermined. Conflict might escalate and lead to non-productive results, or conflict can be beneficially resolved and lead to quality final products (Nnoli, 2006). The traditional view of the effects of conflicts is that conflict is harmful, always having a negative impact, and leading to decline in the standard of living of adversaries and interest groups as the level of conflict increases (Brukum, 2007).

The perception of conflict as something harmful and evitable has begun to fade out (Van Halema \& Rassul, 2013). The argument is that conflict is a natural and inevitable phenomenon with either a negative or positive effect, depending on how the conflict is managed (Alao, 2012; James \& Ryals, 2010; Van Halema \& Rassul, 2013). Bercovitch et al. (2009), for instance, argue that conflict contributes to social change ensuring both interpersonal and intergroup dynamics to remain fresh and reflective of current interests and realities.

After the Cold War, conflict management was grounded in a universalistic conflict management model with standard formula of peace negotiations and accords which sometimes underestimated the uniqueness of conflicts (Williams, 2011). International peacemakers have assumed that the imposition of western liberal democracy and neoliberal economic reforms are the best, if not the only chance for peace (Bercovitch \& Regan, 2004). To date, international organizations like the United Nations (UN), European Union (EU), African Union (AU), and the Economic Community of West African States (ECOWAS) have centred conflict management policies mainly on western-centred conflict management mechanisms.

However, before colonization of Africa, many societies had their own 'indigenous conflict management mechanisms' (Adjei \& Adebayo, 2014). These mechanisms utilised local actors and traditional community-based judicial and legal decision making to manage conflicts. The term 'indigenous' often implies marginalised groups who are dominated politically by another cultural group (Woodley, 2002). In this paper, the term indigenous conflict management mechanisms is used in particular reference to the study area's first settlers (people historically linked by genealogy to a geographical area) and the dominant groups' traditional mechanisms 
for managing conflicts. These mechanisms often seek to involve local authority structures such as chiefs, spiritual leaders, opinion leaders, women's movements, local associations, and other professional groups in managing conflicts (Osi, 2008).

New political, social, and economic structures that came along with colonialism, have not only changed the dynamics of conflict management in Africa in general and particularly in Ghana, but have also usurped the power and relevance of indigenous institutions (practices, beliefs, and norms) opening its ideals to criticisms (Ney, Borteletto \& Maloney, 2013). Indigenous conflict management mechanisms have been criticised and replaced with new legal regimes and law courts. According to the critics, they violate universal standards of human rights and democracy; reflect issues of discrimination against women and lack of voice for children (Boege, 2006). Consequently, western-centred mechanisms such as the formal court system, committees of enquiries, imposition of curfews and military patrols dominate conflict management efforts in Ghana and in particular the Northern Region, yet, the negative aspects of conflicts triumphs (Bukari et al., 2017; Kendie et al., 2014).

Several studies such as Mahama (2003), Awedoba (2009), Sulemana (2009), Ibrahim (2013), Kendie et al. (2014), Godwin (2015) and Bukari et al. (2017), on conflicts in the Northern Region treated the relevance of indigenous conflict management mechanisms as an auxiliary issue. Consequently, this paper explores the relevance of indigenous conflict management mechanisms in the Northern Region of Ghana and how they may be used to effect the termination of enduring or intractable conflicts. In the quest to address the intractable nature of conflicts in the Region, the causes of the conflicts are traced and the mechanisms employed to managing them are examined paying particular attention to indigenous processes used.

The paper is organised into five different sections. The introduction is followed by a review on the theoretical and conceptual issues in conflict and conflict management mechanisms. The third section discusses the methodology, while the fourth presents results and discussion. The last section of the paper presents the general conclusions and policy implications.

\section{THEORETICAL AND CONCEPTUAL ISSUES}

The theoretical framework of this study captures the realist theory of conflict and the indigenous wholistic theory. The combination of these theories is necessary, as each one of them is relevant but insufficient in justifying the phenomena under study. They therefore complement each other in explaining the study. 
Modern realist thinkers such as Jervis, Waltz, and Mearsheimer propounded traditional theories of realism that were first crafted by Hobbes, Machiavelli, and Thucididyes (Demmers, 2012; Dempsay, 2010). Each thinker's conception of realism varies, but they have a common view that the prime source of insecurity is human nature, which is viewed as inherently violent and aggressive (Glaser, 2010; Williams, 2007). Thus, the starting point for the explanation of conflict is the individual level. Realism highlights inherency and traces the root of conflict to the flaw in human nature which is seen to be selfish and engaging in the pursuit of personalised selfinterest defined as power (Behr, 2010). It is also argued that such interest will come into conflict with those of others leading to the inevitability of conflict (Behr \& Amelia, 2009). The theory, therefore, suggests actors should prepare to deal with the outcome and consequences of conflict since it is inevitable, rather than wish there were none. This justifies the need for conflict management.

The indigenous wholistic theory uses the medicine wheel, four directions and circles as an effective and appropriate means and tools for developing healing strategies (Marsden, 2005). They offer a multi-level strategy that is circular in nature which has been practised for thousands of years by lineages (Absolon, 1993; Graveline, 2004; Nabigon, 2006). The following diagram (Figure 1) of concentric circles represents a level of being and illustrates the reciprocal interconnections of self, individual, family, community, nation, society and creation.

At the centre is a tiny circle representing the self. The next circle represents family, then the community, then the nation, society and outward to the ecology of creation. Inclusive to all the levels are the infants, youth, young adults, adults and elders. Each level of being is affected by the historical, social, political and economic and each layer has a spiritual, emotional, mental and physical element. Indigenous wholism considers the connections and the concept 'we are all related' begins to make sense as we perceive each aspect in relation to the whole (Poonwassie \& Charter, 2005). The dynamics of our realities are created because of the relationships and experiences of these interrelationships and interconnections. Absolon (2010) used the Medicine Wheel as a tool to depict Indigenous wholistic theory, which helps us to understand our realities and experiences by considering the influences of all elements of the whole on our individual and collective being. 


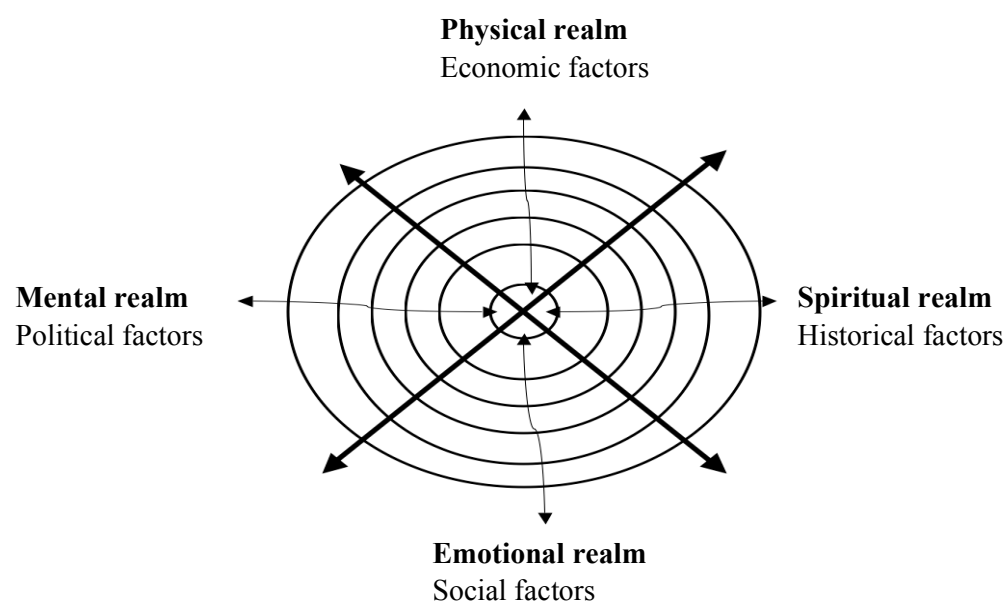

Figure 1: Connections in indigenous wholictic theory

Source: Adopted from Absolon (2010, p.76)

Understanding indigenous people's experiences can initially be comprehended within such a wholistic framework. The above illustration makes it clear that indigenous people's experiences can be framed and contextualised within a historical, social, political and economic framework. Such a wholistic framework provides a concrete tool toward understanding the nature of balance and harmony (Absolon \& Willett, 2005). Conflicts can therefore be managed sustainably when these elements of being are taken into consideration.

Conflict management entails adoption of various measures including establishment of communication links and personal interactions between the adversaries, setting up of mechanisms to end or minimise violence, and seeking commitment of the parties to a solution to their problem (James \& Ryals, 2010). Conflict management does not necessarily imply avoidance, reduction, or termination of conflict. It involves designing effective strategies to minimise the dysfunctions of conflict and enhancing the constructive functions of conflict (Williams, 2011). It is a generic term used to cover the whole gamut of positive conflict handling through the fostering of communication between and among disputants, and drafting of agreements that meet underlying needs (Gellman, 2007). The goal of conflict management is, therefore, to intervene in ways that make an on-going conflict more beneficial and less damaging to all parties.

Conflict does not emerge in a vacuum and for that matter has an origin or a cause. Perceived goals and interest incompatibility is perhaps the most basic cause of conflicts (Sulemana, 2009). Identity defence is also common, particularly in the 
contemporary world where group awareness and rights have assumed high visibility (Collins, 2008; Kendie et al., 2014; Sulemana, 2009; Tonah, 2005; Yelyang, 2016). For Maiese (2003), assertions of injustice are the origin of conflicts. The desire for justice is one that people tend to be unwilling to compromise and individual's sense of justice is connected to the norms, rights, and entitlements that are thought to underlie decent human treatment.

Burton (1990), Rosati, Carroll and Coate (1990), and Rothman (1997) argue that many conflicts are caused by the lack of provision of fundamental human needs. These include basic needs for food, water, and shelter as well as more complex needs for safety, security, self-esteem, and personal fulfilment. The final major origin of conflict has to do with high-stake distributional issues (Coleman, 2003; Coleman \& Deutsch, 2012). Conflicts surrounding who gets what and how much they get also tend to be intractable. The information on the origin or cause of a conflict is prerequisite to handling or managing the conflict (Garrett \& Piccinni, 2012; Hammill \& Bescançon, 2010). The cause of the conflict sometimes suggests the management mechanisms to employ, and the actors or stakeholders to engage to limit the destructive capacity of the conflict.

Utilising indigenous community-based justice mechanisms in conflict management is not new, especially in Africa. Their importance was echoed in 1999 when an international conference was held in Ethiopia (Dejene \& Abdurahman, 2002; Ofuho, 1999). Ofuho (1999) noted that the conference brought to light the experiences of grassroots peacemaking efforts among the communities in Kidepo Valley where cattle rustling were prevalent. According to Ofuho, the people used rituals, symbols, interpretation of myths, and curses to bring conflicts to an end. Indigenous justice systems have been hailed in other African nations as laudable local alternatives for restorative justice. Most notable are the post-genocide Rwanda's traditional Gacaca and post-war Uganda's Mato Oput.

Indigenous conflict management mechanisms in managing localised or communitybased conflicts cannot be overemphasised. Parties to a conflict are enjoined to adopt an integrative (win-win) approach with each having the opportunity to present their case without recourse to counsel as found in adversarial systems. This consequently makes the approach affordable and cheaper. Menkhause (2000) in the same vein notes that indigenous mechanisms tend to be process-oriented and not product-oriented. That is, they focus on managing rather than resolution. Indigenous conflict management mechanisms are usually better attuned to the needs of local communities (Kwesi, 2013). This is because they use the inquisitorial and restorative approaches to conflict management instead of the adversarial, winner-looser approach of litigation (Isike \& Uzodike, 2011; Kah, 2011; Kwesi, 2013). 
In spite of this relevance, indigenous conflict management mechanisms are limited in space, that is, they are confined to a relatively small community context; clan, village, or neighbouring communities. They have been challenged as only applicable to and useful in managing simple disputes - matrimonial disputes, intra-family quarrels, land disputes, among others which are not as complex or threatening as conflicts of national proportions (Osaghae, 2000). The customary laws applied may evolve from such small societies and may not be applicable to other societies (Zartman, 2000). A major argument against indigenous mechanisms is that they violate universal standards of human rights and democracy, reflect issues of discrimination against women, and lack a voice for children (Boege, 2006).

\section{METHODOLOGY}

The key guiding principles underlying the selection of the study areas are: high incidence of conflicts in an area; protracted, deep-rooted, relapsed nature of the conflicts; and the violent nature of the conflicts (the use of arms, injuries, property destruction, and deaths). The districts that emerged from the guiding principles were the Bunkprugu-Yunyoo and Central Gonja Districts (Kendie et al., 2014). The choice of the approach to the study was qualitative since the study is meant to achieve a deeper understanding and appreciation of indigenous conflict management mechanisms, with the view to developing theories for sustainable management of conflicts.

The multiple case study design was adopted for the study. Yin (2003) emphasised that multiple cases strengthen the results by replicating the patterns thereby increasing the robustness of the findings. Each case (Bunkpurugu-Yunyoo and Central Gonja) will serve to confirm or disconfirm the conclusions drawn from the others. Purposive sampling technique dominated the study. Traditional leaders from the dominant ethnic groups were part of the study. The indigenous people (adversaries) were also purposively sampled for the study. District Assemblies' officials, the District Security Council, the House of Chiefs, WANEP, and Catholic Diocese were all purposively selected for information. The sample size for the entire study was forty-three respondents. The breakdown of this is shown in Table 1. 
Table 1: Summary of sample size

\begin{tabular}{|c|c|c|c|c|}
\hline Response Unit & $\begin{array}{l}\text { Bunkpurugu- } \\
\text { Yunyoo }\end{array}$ & $\begin{array}{l}\text { Central } \\
\text { Gonja }\end{array}$ & $\begin{array}{l}\text { Regional } \\
\text { officers }\end{array}$ & Total \\
\hline \multicolumn{5}{|l|}{ Traditional leaders/Adversaries } \\
\hline Jamong family & 2 & & & 2 \\
\hline Jafouk family & 2 & & & 2 \\
\hline Kokombas & 2 & & & 2 \\
\hline Bimobas & 2 & & & 2 \\
\hline Awusi family & & 1 & & 1 \\
\hline Jinapor family & & 1 & & 1 \\
\hline \multicolumn{5}{|l|}{ Keyinformants } \\
\hline District Assembly officials & 1 & 1 & & 2 \\
\hline Regional Security Council & & & 1 & 1 \\
\hline District Security Council & 1 & 1 & & 2 \\
\hline House of Chiefs & & & 1 & 1 \\
\hline WANEP & & & 1 & 1 \\
\hline Catholic Diocese & 1 & & 1 & 2 \\
\hline Male Focus Group Discussion & 6 & 6 & & 12 \\
\hline Female Focus Group Discussion & 6 & 6 & & 12 \\
\hline Total & 23 & 16 & 4 & 43 \\
\hline
\end{tabular}

Source: Fieldwork (2017)

In-depth interviews, focus group discussion, and observation were the data collection methods for this study. Two focus group discussions each (men and women) were organised in the selected districts for the study to discuss the phenomena under study. Through preliminary engagements with some key informants at Bunkpurugu-Yunyoo district, it was revealed that a blood burial ceremony between the Jamong and Jafouk families on the chieftaincy conflict that has raged for years was to be performed. The process was observed.

Data was analysed using cross-site analysis. Using the multiple cases, 'a typical format to first provide a detailed description of each case and themes within the case, called a within-case analysis' (Creswell 1998, p.63) was adopted. The withincase analysis is followed by a thematic analysis across the cases, referred to as cross-case analysis or cross-site synthesis (Creswell, 1998; Yin, 2003). Accordingly, all the details with respect to each study area were organised into the respective case file manually. 


\section{RESULTS AND DISCUSSION}

\section{Nature and Cause of the Conflicts}

Two conflicts are concurrently going on in the Bunkpurugu-Yunyoo District. These are: the chieftaincy succession conflict between the Jafouk and Jamong families from the same clan (Louk clan) of the Bimboba ethnic group and the ethnic conflict between Kokombas and Bimobas regarding access to and control over land. Bimobas in the Bunkpurugu traditional area migrated from Togo to settle in the area because of the vast nature of land to serve their interest in farming. Kokombas originally inhabited the place, but then, they kept shifting outward since it is believed that they were not comfortable co-inhabiting with different people. Both the Kokombas and Bimobas were acephalous groups and recognised the Nayiri (overload of the Mamprugu Traditional Area) as their landlord. The Nayiri initially assigned people as 'caretakers' of the land and not chiefs. But, as time went by, these titles became chieftaincy titles for these acephalous groups.

Although there are other clans within the Bimoba ethnic group such as the Buuk, Temong and the Bawk, the Louk clan was first to settle in Bunkpurugu and therefore, became the caretakers. The Louk clan is the predominant clan in both Bunkpurugu and Nakpanduri. Due to this, the Bunkpurugu and Nakpanduri chieftaincy title come from this clan. This clan is made up of the Jafouk and Jamong members who hail from the same grandparents, a village called Loukporuk.

The interviews revealed that, the Jamong family happened to be the first to ascend to the title and ruled for three consecutive regimes, from Bait (chief) Najonk to BaitJamong and to Bait Mong. They argued that the Bunkpurugu skin is reserved for only members of the Jamong family and had nothing to do with succession turns between their family and another family. According to the narratives, their father was the first to settle in Bunkpurugu among the Bimobas and was the first to ascend to the title. It, therefore, means that any individual outside this family is not qualified to be enskined as Bunkpurugu chief.

Contrary to the above assertion by the Jamong family, the Jafouk family argued that, they are equally qualified to be enskined as Bunkpurugu chiefs. According to the family, nothing prevents them from contesting for a vacant Bunkpurugu skin since they are Bimbobas and from the Louk clan. 'All we need is to present a candidate to the Nayiri who by the Nayiri's own criteria, can manage the traditional area on his behalf' (Key informant from Bunkpurugu, $9^{\text {th }}$ March, 2017).

A validation at the Nayiri's palace revealed more intriguing information concerning the status quo of succession of chieftaincy at Bunkpurugu traditional area. 
According to the key informant, Nayiri has the prerogative to choose from either side (Jafouk or Jamong) or even any person from any other clan apart from the Louk clan to ascend to the skin since there is no written or verbal succession plan in the traditional area. Anytime there is a vacant Bunkpurugu skin, individuals from all the clans are qualified to present candidates to the Nayiri for consideration. The Nayiri through consultations and background checks selects one of these candidates

Unhappy with the Nayiri's choice of the Jafouk family's candidate Bait Nong, the Jamong family sent the matter to court. For eight years, the Regional House of Chiefs failed to rule on the case, so Bait Najong, remained on the skin till he passed on in 2006. The Nayiri enskinned Alhaji Abuba, who also was from the Jafouk family, to succeed Bait Nong. He is currently the chief of Bunkpurugu. The Jamong family perceived this as an unjust treatment but continued battling out their case at the Regional House of Chiefs. For ten (10) years now, the case is still pending in the court. This period has been characterised by tension in all facets of life between the two families especially each time they return from court.

The other conflict in the Bunkpurugu-Yunyoo District is an inter-ethnic conflict between Kokombas and Bimobas regarding access to and control over land. Kokombas, Bimobas, and Mamprusis are the predominant inhabitants in the district. However, both Bimobas and the Kokombas recognise the Mamprusis as owners of the land. The conflict between the two settler ethnic groups - Bimobas and Kokombas - has to do with them perceiving each other as not having usufruct right of the land and for that matter should not be deciding who has access to the land.

The conflict also has to do with a stereotype of the Kokomba ethnic group as being a lower class of humans. The in-depth interviews with the District Assembly Officials revealed that Kokombas are less educated, less privileged, not economically rich people, and live a haphazard life. On the other hand, the Bimobas see themselves as high-class people, having a greater number of educated individuals and economically rich people.

The Central Gonja District also presents two major conflict situations; a battle of 'legitimacy of authority' between the Yagbonwura (overlord of the Gonja traditional area) and his surrogate Bawah Awusi on one side against Abdulai Mahama Jinapor, the chief of Bupei on the other side. The other conflict was a land conflict in Mpaha between the Tijaniyya and the Alsuna Muslim sects regarding access to land.

In the first case, at a traditional council meeting at the Yagbonwura's palace at Damango, one of the subordinates of the chief of Bupei - Abdulai Mahama Jinapor, fired gunshots into the air. Shooting a gun into the air in the presence of the 
Yagbonwura was interpreted as a sign of disrespect to the Yagbonwura's authority since it was against the customary practices of the Gonja tradition. Yagbonwura and the traditional council decided to sanction the Buipewura, by taking the Buipe skin title from him (deskinment) and giving it to another person. Bawah Awusi was chosen and enkinned immediately Jinapor was told he no longer holds the Buipe skin title.

The deskinned Buipewura, Abdulai Mahama Jinapor, sent the case to the Tamale High Court challenging the authority of the Yagbonwura to deskin him. He argued that, per the traditional status quo, Kagbapewura, who performs the final enskinment of a Yagbonwura is the same person from whom a Buipewura draws his power and authority. After enskining a Yagbonwura, per the customs of the Kingdom, Kagbapewura does not set his eyes on the Yagbonwura again and so delegates the Buipewura to attend traditional meetings on his behalf. Yagbonwura cannot, therefore, deskined a Buipewara, a representative of the Kagbapewura at traditional council meetings. He won the case at the Tamale High Court. The Yagbonwura appealed against the ruling of the Tamale High Court at the Appeals Court in Accra. Here too, the deskinned Buipewura, was pronounced the winner.

As regards the cause of the conflicts, the first structural cause in the BunkpuruguYunyoo District is the gradual centralization of the acephalous ethnic groups in the area. Ethnic groups which previously had no centrality and recognised leaders were now centralising and were faced with a challenge of who gets what. In the case of the chieftaincy succession, the Bimoba ethnic group had no chiefs and for that matter no succession plans. Consequently, key issues detailing who qualifies to be the chief of the place are lacking. Another structural cause directly linked to the gradual centralization of the settler ethnic groups is history. In both the chieftaincy succession and land conflict cases, the parties construe history to suit their stance. In effect, each side has a history that justifies their actions making it difficult to compromise.

The finding that parties construe history to suit their stance is in line with the realist theory. Realism highlights inherency and traces the root of conflict to the flaw in human nature which is seen to be selfish and engaging in the pursuit of personalised self-interest defined as power (Behr, 2010). It is also argued that such interest will come into conflict with those of others leading to the inevitability of conflict (Behr \& Amelia, 2009).

Furthermore, prolonging the conflicts is the issue of social relationship. Strong emotions, stereotypes, poor communication, and historic negative patterns characterise the relationship. In the particular case of the conflict between the two 
ethnic groups, Kokombas are seen as lower class people and therefore lack respect and recognition in the society. This stereotype is inculcated into the younger generation and reinforces the lines of divisions between the two ethnic groups. This is an expression of what Collins (2008) describes as identity which is a major cause of conflict. According to Collins, when group members feel their sense of self is threatened or denied of legitimacy or respect, conflict arises.

\section{Indigenous Conflict Management Mechanism}

\section{The Nayiri's Court}

The Nayiri's court remains the highest seat of authority among the Manprusis, Bimobas, and the Kokombas in the area. Only mega cases involving different ethnic groups, land, and chieftaincy are adjudicated on in the Nayiri's court. The process of the mechanism is both mediation and arbitration process, which involves the parties or actors selected by any of the parties to the conflicts, the Nayiri, and his elders. A case is registered at the court for determination through self-initiation by the Nayiri upon information reaching him informally or when one party lodges a complaint to the chief through the wulan (chief linguist). A day is set for the process to commence within three to seven days after a complaint has been lodged by which time all parties to the conflict would have been duly informed and invited. Either summoned by the Nayiri or a party goes to the chief's palace voluntarily to report a case, a token (cola nuts) is given out by the parties before the process begins.

As a general procedure, parties to the conflict are made to exchange greetings. The reason is that, enemies do not sit together with the Nayiri according to the customs and tradition. The greeting, therefore, serves as an indicator of the parties' readiness to resolve their differences. At the zongni (a big round hall where the chief receives visitors and holds court), parties are made to present their cases formally for determination. The chief and his elders listen to both sides carefully then the case is adjourned to the next sitting. Within seven days, the next sitting is organised. According to a key informant, the chief and his elders use this period to analyse the cases presented by the parties to enable them identify areas where sacrifices can be made by either of the parties or both of the parties to arrive at an acceptable solution (agreement) to all parties.

Through experience, consultations, and soothsaying, the chief and his elders make a binding decision. The final decision is communicated to the parties on the third sitting. There is no opportunity to appeal the decision in the Nayiri's court. It is at this stage of the management process that the blood burial ceremony is performed to seal the acceptance of the outcome of the process. The blood burial serves as the final stage of the management process. The blood burial ceremony is a significant 
ceremony which seeks to appease the gods of the land for an offence which was committed either advertently or inadvertently by a kinsman or an alien living in the community which could attract the anger or otherwise of the gods of the land.

Owing to the land conflicts between the Bimobas and Kokombas, which led to the killing of innocent persons and destruction of properties, the Nayiri's court was used and the blood burial was performed between Kambatiak and Gbankoni communities, supervised by the leaders of the parties to the conflict with a representative of the Nayiri, and the Navrongo-Bolgatanga Catholic Diocese and witnessed by the Northern Regional Minister with his entourage.

Both parties to the conflict presented their cases, indicating property right to the contested land supported by oral history but not legal documents. Such property rights over the land have followed different forms over time and have shaped debate concerning authority over resources according to the narratives from the key informant at the Nayiri palace. As part of the binding decisions made by the Nayiri and his elders in this particular case, the disputed land was to be reserved for the building of a school facility. In addition, each faction (the Bimoba and the Kokomba ethnic groups) was charged to provide three local fowls, one goat, millet flour, and a big jerry can, i.e. about five to six gallons of pito (a local brew from guinea corn) for the blood burial ceremony as determined by the soothsayer.

The items were presented at the site for the ritual and used in the pacification process. After these items were inspected, the animals were slaughtered close to the pit and the blood made to run gently into the pit. Parties were made to promise to live in peace and to cooperate with each other. A final word came from the representative of the Nayiri who urged the parties to keep to their promises as they could suffer calamity and end the same way as the animals have ended should an individual or group of individuals disturb the peaceful path they have agreed upon and now make promise to their gods and ancestors. This was followed by merrymaking with the pito (a local alcoholic drink) under the shed of a big tree close to the pit (see Plate 1 to 4 ). 


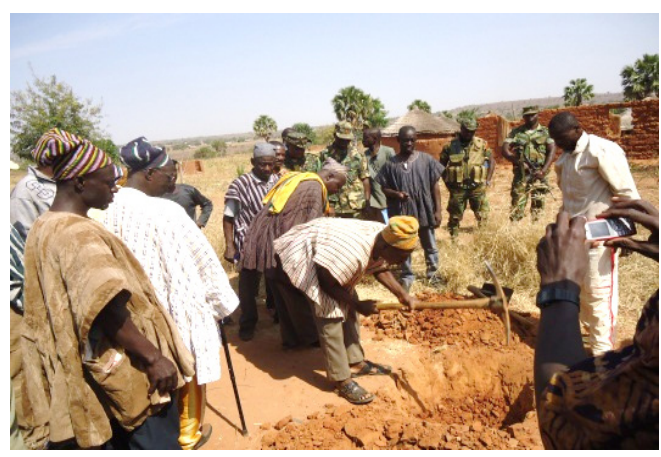

Plate 1: Regional minister with his security guards at the pit digging site

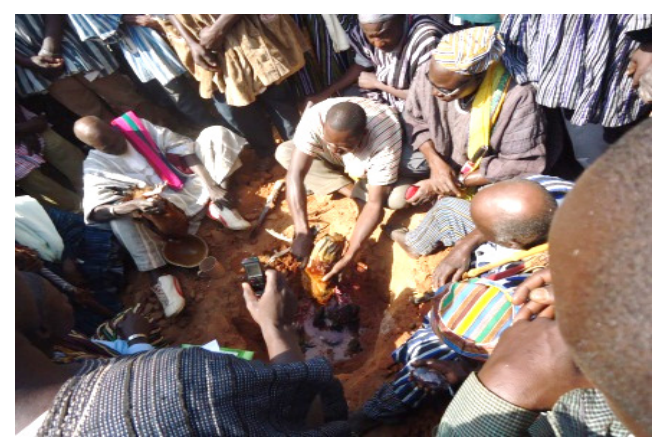

Plate 3: Slaughtering the animals for the blood to be buried

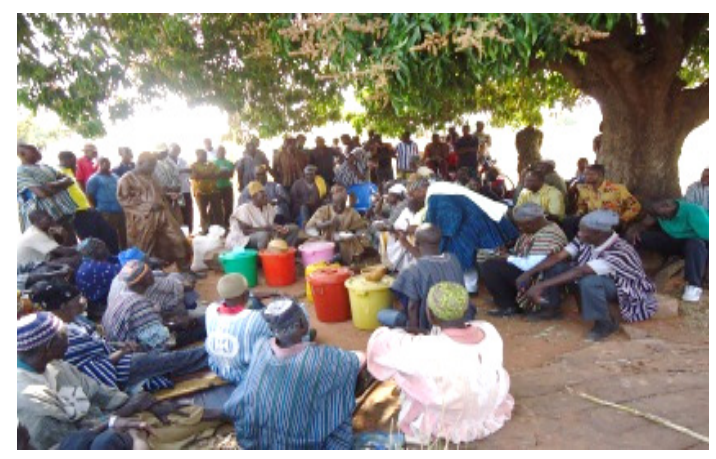

Plate 2: Inspection of the items by the leaders of the two factions

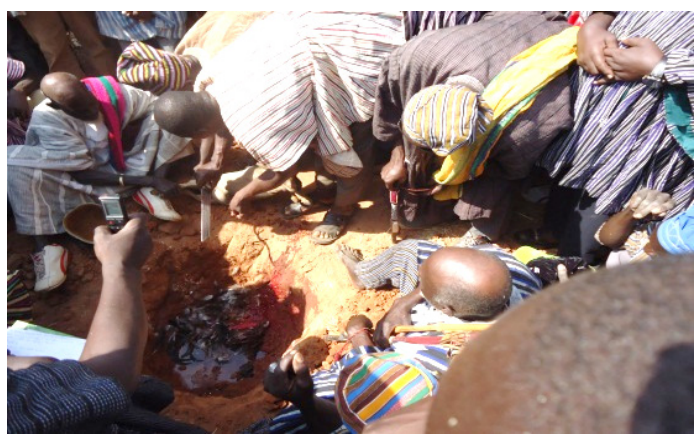

Plate 4: Pacifying the gods after slaughtering the animals

Photocredit: Ibrahim (2017)

\section{Traditional Committees}

The chieftaincy conflict in the Central Gonja District between Abdulai Jinapor and Bawah Awusi was finally put to rest through the constitution of a traditional committee by the traditional c ouncil of the Gonja Kingdom. As part of the Gonja tradition, in times of difficulties in the use of the already existing structures to manage conflicts, and, also, with the main objective of ensuring fairness of processes and sustainable results, the Yagbonwura and his council constitutes a traditional committee to undertake mediation processes. The supreme traditional court is the Yagbonwura's court which consists of the paramount chief, and some elders representing the five divisions: Bole, Tulewe, Daboya, Kpembie, and Kusawgu traditional areas. This court, however, was perceived as inappropriate to handle the Buipe chieftaincy conflict in which the Yagbonwura was a party to. Even though the Tamale High court and the Appeals court in Accra pronounced Abdulai Jinapor as the legitimate chief of Buipe, he was not recognised by the Gonja traditional council and for that matter, could not attend traditional council meetings. Confrontations therefore continued between Abdulai Jinapor and Bawah Awusi in the Buipe traditional area. To resolve the problem, the Yagbonwura and his 
council constituted a traditional committee to undertake mediation processes. The traditional committees mostly constitute other chiefs within the kingdom but from different traditional areas and are not direct parties to the conflict. This ensures neutrality of the third party to the conflict.

According to the narratives, the committee was made up of the Damongowura [Chairman], Kpansheguwura, Choriwura, Mankpanwura [represented by Sorwura], Wasipewura, Kpembewura [represented by Kanyasiwura], Bolewura [represented by Salawura], Tuluwewura, Kusawguwura and Lepowura. The narratives also indicated that before the committee commenced the management process, the Yagbonwura as a party to the conflict promised to abide by the recommendations of the committee whether favourable or unfavourable. According to the key informant, the Yagbonwura said:

I have given you this mantle to bring peace to our Kingdom and for this reason, I will take whatever decisions you come out with in good faith. If I am wrong, let me know I am wrong. May our ancestors guide us all in this... (key informant in Buipe, $2^{\text {nd }}$ April, 2017).

The committee met the factions together on two occasions, met the factions separately, and also met several times without the factions according to the key informants. It was a means of weighting evidence through cross-checking and corroborating of the facts of the conflict. After these series of meetings, the committee's final report recommended the following as guidelines:

i. all chiefs enskined during the reign of Buipewura Awusi Jewu Bawa Lebu II would still remain as legitimate chiefs and all lands sold considered valid to their owners without the need for them to change or acquire new documents

ii. the rival Bupie Chief, Bawah Awusi will be given another chieftaincy title known as Danyapiwura to pave way for the re-enskinmnt of Abdulai Mahama Jinapor as the substantive Buipewura.

iii. Abdulai Mahama Jinapor should be re-enskined as the substantive Buipewura

iv. any development agenda or project to be carried out in Buipe must come under the watch and supervision of Buipewura Mahama Jinapor II and the deskinned Buipewura Lebu II for the sake of peace and unity to prevail.

Emphasis must be laid here that all the agreements were verbal, there were no sealed and signed documents to their effect. Customarily, the kingmakers performed all the necessary rituals to seal the agreements and Mahama Jinapor was re-enskinned as Buipewura, a title he held since 11th June 2008 until he was deskinned on the 14th May 2010 by the Traditional Council. He pledged to work closely with Bawah Awusi to bring development to the area. 


\section{The Use of Ademang}

The use of Ademang is another indigenous mechanism for conflict management in the Gonja Kingdom and for that matter in the Central Gonja District. Ademang (plural) or Kedemang (singular) literally means smaller gods/totems in the local dialect. These Ademang are used in the management of conflicts in all Gonja settlements. Conflicts that have spiritual dimensions involve incantations, curses, witchcraft and oath-taking, among others, are brought before the traditional and spiritual leaders including the custodians of deities, and soothsayers. For example, one party may invoke a curse by using the name of a smaller god (Sonyokipo) or a deity to harm another person for perceived wrong doing. Once the afflicted party realises through divination that they have been cursed, the accused is requested to reverse or remove that curse by performing the necessary rituals at the appropriate quarters and going through the necessary traditional/cultural process.

Apart from serving as intermediaries between the ultimate God and humanity, the basic feature of the Ademang is that they are dreaded and as such worshipped with utmost reverence and fear. The diviner or priest takes time to consult the spirit world and explains the supernatural aspect of events and makes issues associated with conflict convincing, intelligible and therefore acceptable to the parties. The priests pronounce judgement and prescribe the sacrifices to atone for wrong doing and appease the anger of the ancestors. The priests of the Ademang serve as mediators between conflict individuals or groups and the ancestor spirits.

In analysing the mechanisms above, the chief's court system of managing conflicts is part of a well-structured, time-proven social system geared towards reconciliation, maintenance, and improvement of social relationships in the Gonja Kingdom and for that matter in the Buipe traditional area. The processes and regulations are deeply rooted in the customs and traditions of the Gonjas. It emerged from the focus group discussions that the relevance and utility of the processes lie in the fact that they strive to restore a balance, to settle conflict and eliminate disputes. What is evident is that at the community level, there are well-established traditional leadership and consultative structures and processes through which disputes are settled.

Proceedings at the chief's court are purely arbitration processes with the chief and his elders serving as the arbiters. This is because the chief and his elders make the final decision which is binding on all parties. Since the chief's court is located within the community and no money is paid for reporting a case for adjudication, the process is accessible and affordable. The direct participation by the adversaries and the use of the local languages make the arbitration process transparent leading to acceptable outcomes. This supports the views of Beall and Mduduzi (2009), Boege 
et al. (2009), MacGinty (2008) and Menkhaus (2000) that indigenous mechanisms have a feature of inclusive participatory approach at all levels of the conflict.

In this mechanism, focus goes beyond resolution to managing. Outcomes are meant to heal wounds as the guilty parties are made to pay some compensation to those they offend. The promises made at the end of the process by the parties are meant to ensure peaceful co-existence between them. The chief's court uses short duration for the arbitration process. This leads to quick delivery of justice which prevents relapsed conflicts. The information concurs with Braeuchler and Thomas' (2007), Brigg's (2008), and Faure's (2000) assertions that, traditional conflict management mechanisms tend to be process-oriented, not product-oriented; that is, they go beyond resolution to management.

Another major strength of the traditional mechanisms in the Central Gonja District worth noting is the constitution of a 'neutral' committee made up of the chiefs from other traditional areas to adjudicate matters. The composition of the traditional committees which considered the history, political, and social relations demonstrates the Gonja notion of participatory democracy. This builds the trust of conflicting parties in the process concerning neutrality. It ensures fairness, and also produces sustainable results. This mediation process also produces a 'winwin' result for adversaries. With reference to the Buipe chieftaincy conflict, the committee recommended another chieftaincy title for Bawah Awusi to pave way for the re-enkinment of Abdulai Jinapor as Buipe chief. This suppressed the high tensions between the supporters of the factions since at the end both parties took home skin titles. This is in line with the indigenous wholistic theory. The theory states that, indigenous people's experiences can be framed and contextualised within a historical, social, political and economic framework which provides a concrete tool toward understanding the nature of balance and harmony (Absolon \& Willett, 2005).

With regard to the use of the Ademang, the fear of supernatural powers, ancestors and other traditional divinities, personal shame and deterrence are the elements of the internal social controls processes. The fear of the wrath of the Ademang ensures the acceptability of the outcomes. This is in congruence with the findings of Bob-Manuel (2000), Brock-Utne (2001), Bercorritch, Kremenyuk and Zartman (2009), Okere (2013) and Ogunesan (2014) that the indigenous conflict management mechanisms is cooperative and does not give opportunity for the accused to deny charges because of the fear of the native gods. 


\section{CONCLUSION AND POLICY IMPLICATION}

Indigenous mechanisms of conflict management have proven to be suitable for settling disputes at the local level due to their acceptable outcomes. Yet, some of the conflicts are now in the courts principally because the indigenous mechanisms are not allowed to work. This is because chiefs and elders who act as third parties in the management processes abuse the mechanisms with arbitrary decisions. The processes currently are sometimes discriminatory. Nonetheless, the mechanisms have been observed and proven to be immediate and meaningful, accessible, and affordable. The use of local language is well understood by all parties and processes and procedure are well attuned to local needs as they produce quick justice to the people.

Through the District Assemblies, Regional and District Security Councils, and Peace Councils, government should develop a comprehensive programme to incorporate aspects of both the indigenous and western-centred judicial structures for the purposes of legitimacy and better fulfilment of local needs. In other words, an enquiry leading to the intersection of the two separate but interrelated ideologies should be carried out as it does benefit from the strengths of each approach and offsets their different weaknesses.

\section{References}

Absolon, K. (1993). Healing as practice: Teachings from the medicine wheel. Unpublished Manuscript. Available at: https://www.researchgate.net/ publication/303961857

Absolon, K. (2010). Indigenous wholistic theory: A knowledge set for practice. First Peoples Child \& Family Review, 5(2), pp. 74-87.

Absolon, K. and Willett, C. (2005). Putting ourselves forward: Location in Aboriginal research methodology. In L. Brown \& S. Strega (Eds.), Research as resistance: Critical, indigenous and anti-oppressive research approaches (pp. 97-126). Toronto: Canadian Scholars Press. Available at: https://kinasevych.ca/2017/og/19/ absolon-willett-2005-putting-ourselves-forward-location-in-aboriginalresearch/

Adjei, J.K. and Adebayo, A.G. (2014). Indigenous conflict resolution strategies in Monarchical systems: Comparison of nature, effectiveness, and limitations of the Yoruba and Akan models. In A. G. Adebayo, J. J. Benjamin \& B. D. Lundy (2014), Indigenous conflicts management strategies, global perspectives (pp. 85102). London: Lexington books. 
Alao, D.O. (2012). Anassessment ofethno-communal conflicts in Saare/Tsaragicommunities of Kwara State, Nigeria. Unpublished Ph.D. Thesis, Ilishan, Babcock University.

Awedoba, A.K. (2009). An ethnographic study of Northern Ghanaian conflicts: Towards a sustainable peace. Accra: Sub-Saharan Publishers. Available at: http://197.255.68.203/handle/123456789/1293

Beall, J. and Mduduzi, N. (2009). Indigenous institutions, traditional leaders and elite coalitions for development: The case of greater Durban, South Africa (Crisis States Working Papers Series No. 2, Working Paper No. 55). London: Crisis States Research Centre. Available at: http://www.crisisstates.com/Publications/ publications.htm

Behr, H. and Amelia, H. (2009). Misreading in IR theory and ideology critique: Morgenthau, Waltz, and Neo-Realism. Review of International Studies, 35(2), pp. 327-349.

Behr, H. (2010). A history of international political theory: Ontologies of the International. Houndmills: Palgrave Macmillan.

Bercovitch, J, Kremenyuk, V. and Zartman, W. (2009). The Sage handbook of conflict resolution. London: SAGE Publication. Available at: http://dx.doi. org/10.4135/9780857024701.n1

Bercovitch, J. and Regan, P. (2004). Mediation and international conflict management: A review and analysis. In M. Zeev, A. Mintz, T.M. Clifton, G. Palmer and J.S. Richard (Eds.), Multiple paths to knowledge in international relations (pp. 249272). Lanham, MD: Lexington.

Bob-Manuel, I. (200o). A cultural approach to conflict transformation: An African traditional experience. Unpublished Manuscript.

Boege, V., Brown, M.A., Clements, K.P. and Nolan, A. (2009). On hybrid political orders and emerging states: what is failing - states in the global south or research and politics in the west? The Berghof Handbook Dialogue Series 8, pp. 15-36. Available at: https://scholar.google.com/citations?user=1OadmEoAAAAJ\&hl=en

Boege, V. (2006). Traditional Approaches to conflict transformation - Potentials and limits. In M. Fiischer, H. Giebmann \& B. Schmelzle (Eds.), Berghof handbook for conflict transformation (pp. 1-21). Berlin, Germany: Berghof research centre for Constructive Conflict Management. Available at: http://www.gsdrc. org/document-library/traditional-approaches-to-conflict-transformationpotentials-and-limits/

Braeuchler, B. and Thomas, W. (2007). Die Revitalisierung von Tradition: Im (Ver) Handlungsfeldzwischenstaatlichem und lokalemRecht. In Zeitschrift Fuer Ethnologie, 132, pp. 5-14. 
Brigg, M. (2008). Networked relationality: Indigenous insights for integrated peacebuilding (Hiroshima University Partnership for Peacebuilding and Social Capacity Discussion Paper Series No. 3). Hiroshima: Hiroshima University.

Brock-Utne, B. (2001). Indigenous conflict resolution in Africa. Draft presented to the weekend seminar on indigenous solutions to conflicts, Institute for Educational Research, University of Oslo, Oslo, Norway. https://www.researchgate.net/ publication/238729189

Brukum, N.J.K. (2007). Chieftaincy and ethnic conflicts in the Northern Region of Ghana. In S. Tanah (Ed.), Ethnicity, conflict and consensus in Northern Ghana (pp. 98-115). Accra: Woeli Publishing Services.

Bukari, F.I.M., Kendie, S.B., Sulemana, M. and Galaa, S.Z. (2017). The effects of chieftaincy and land conflicts on the socio-political development of Northern Ghana. International Journal of Social Science Research, 5(1), pp. 101-119.

Burton, J. (1990). Conflict: Resolution and prevention. Vol.1. London: Macmillan.

Coleman, P.T. (2003). Characteristics of protracted, intractable conflict: Toward the development of a meta framework-I. Peace and Conflict. Journal of Peace Psychology, 9, pp. 1-37.

Coleman, P.T. and Deutsch, M. (Eds.) (2012). Psychological components of sustainable peace. New York, NY: Springer Available at: http://www.springer.com/us/ book/9781441999931

Collins, S.D. (2008). Module 3: Managing conflict and workplace relationships. Managerial Communication Series Volume 3. Retrieved from www.books.google. com.gh/books?isbn=0324584199

Creswell, J.W. (1998). Qualitative inquiry and research design: Choosing among five traditions. Thousand Oaks, Calif: Sage Publications.

Dejene, A. and Abdulrahman, A. (2002). The Root Causes of Conflict among the Southern Pastoral Communities of Ethiopia: A Case Study of Borana and Degodia. In: Conflict in the Horn: Prevention and Resolution. Report of Ethiopia National Workshop. Addis Ababa. OSSREA pub.

Demmers, J. (2012). Theories of violent conflict: An introduction. Oxon: Routledge.

Dempsay, J.A. (2010). Traditional dispute resolution and stability in Afghanistan. Washington DC: United State Institute of Peace. Available at: https://www. usip.org/publications/2010/02

Faure, G.O. (2000). Traditional conflict management in Africa and China. In I. W. Zartman (Ed.), Traditional cures for modern conflicts - African Conflict "medicine" (pp. 153-165). Boulder, CO: Lynne Rienner. 
Garrett, N. and Piccinni, A. (2012). Natural resources and conflict: A new security challenge for the European Union (A Report for SIPRI). Unpublished Manuscript.

Gellman, M.I. (2007). Powerful cultures: Indigenous and western conflict resolution processes in Cambodian. Peacebuilding Journal of Peace Conflict \& Development, 11, 1-28. Available at: www.peacestudiesjournal.org.uk

Glaser, C.L. (2010). Rational theory of international politics: The logic of competition and cooperation. Princeton: Princeton University Press.

Godwin, N.A. (2015). Building sustainable peace in the Buipe traditional Area in the Northern Region, Ghana. Unpublished MPhil thesis, Institute for Development Studies, College of Humanities and Legal Studies, University of Cape Coast.

Graveline, F.J. (2004). Healing wounded hearts. Halifax: Fernwood Publishing.

Hammill, A. and Bescançon, C. (2010). Promoting conflict sensitivity in transboundary protected areas: A role for peace and conflict impact assessments (Handbook Dialogue Series, No. 8.). Paper prepared for the workshop on Transboundary Protected Areas in the Governance Stream of the 5th World Parks Congress, Durban, South Africa.

Ibrahim, M.G. (2013). Land use conflicts: The case of Fulani herdsmen and indigenous farmers in Gushiegu District of Northern region of Ghana. Unpublished MPhil thesis, Institute for Development Studies, Faculty of Social Sciences, University of Cape Coast.

Isiske, C. and Uzodike, U.O. (2011). Towards an indigenous model of conflict resolution: Re-inventing women's role as traditional peacebuilders in neo colonial Africa. African Journal on Conflict Resolution, 11(2), 32-58. Available at: http://www.accord.org.za/ajcr-issues/towards-an-indigenous-model-ofconflict-resolution/

James, S. and Ryals, L. (2010). A re-evaluation of conflict theory for the management of multiple, simultaneous conflict episodes. International Journal of Conflict Management, 21(2), pp. 186-201.

Kah, H.K. (2011). Regulatory societies, peacebuilding and maintenance in the Cross River region of Nigeria and Cameroon. West African Conflict Peacebuilding Review, 1(2), pp. 50-73.

Kendie, S.B., Osei-Kufuor, S.B. and Adutwum, P. (2014). Spatial analysis of violent conflicts in Ghana. Ghana: UNDP-Ghana. Available at: http://www.cco.regeneronline.de/2016_2/abstr_engl/osei-kufuor2016_abstr_engl.htm

Kwesi, A. (2013). Report on access to justice - scoping study of the justice (formal and informal) sector in Ghana. Unpublished Manuscript. 
Mac Ginty, R. (2008). Indigenous peace-making versus the liberal peace. Journal of the Nordic International Studies Association, 43(2), pp. 139-163.

Mahama, I. (2003). Ethnic conflicts in Northern Ghana. Tamale: Cyber Systems.

Maiese, M. (2003). Causes of conflicts and disputes. Washington, DC: Management Systems International (MSI).

Marsden, D.M. (2005). Indigenous wholistic theory for health: Enhancing traditionalbased indigenous health services in Vancouver. University of British Columbia, pp. 109-194.

Menkhause, K. (2000). Traditional conflict management in contemporary Somalia. In I. W. Zartman (Eds.), Traditional cures for modern conflicts: Africa conflict "medicine" (pp. 183-199). Boulder, CO: Lynne Rienner.

Nabigon, H. (2006). The hollow tree: Fighting addiction with traditional native healing. Montreal \& Kingston: McGill-Queen's University Press.

Ney, T., Borteletto, C. and Maloney, M. (2013). Exploring strategies to revive traditional decision-making in the context of child protection in Northern British Columbia. First Peoples Child \& Family Review, 7(2), pp. 60-72.

Nnoli, O. (2006). National security in Africa: A radical new perspective. Enugu: Snaap Press Ltd.

Ofuho, C.H. (1999). Community conflict resolution and reconciliation in the Kidepo, Valley of Eastern Equatoria, South Sudan: Some lessons from grassroot practices of peacemaking. Paper presented to the All-Africa Conference on African Principles of Conflict Resolution and Reconciliation, Addis Ababa, Ethiopia, 8th - 12th November, 1999.

Ogunesan, T. (2014). Traditionalists join search. Nigerian Tribune. May 2.

Okere, T. (2013). African culture: The past and the present as an indivisible whole. Retrieved fromhttp://www.crvp.org/book/serieso2/ii - 3/chapter_i.htm retrieved 05/06/14

Onwuzuruigbo, I. (2011). Horizontal inequalities and communal conflicts: The case of Aguleri and Umuleri communities of South-Eastern Nigeria. Unpublished Manuscript.

Osaghae, E.E. (200o). Applying traditional methods to modern conflicts: Possibilities and limits. In I.W. Zartman (Ed.), Traditional cures for modern conflicts: African conflicts. Medicine (pp. 153-165). Boulder, CO: Lynne Rienner. 
Osi, C. (2008). Cultivating culturally appropriate methods in lieu of litigation. Journal of Conflict Resolution, 10, 175-176. Available at: http://cardozojcr.com/ voliono1/163-232.pdf

Otite, O. (1999). On Conflicts, their Resolutions, Transition and Management: in Otite, O. and Albert, I.O (eds), Community Conflicts in Nigeria: Management, Resolution and Transformation, Ibadan, spectrum Books Ltd.

Poonwassie, A. and Charter, A. (2005). Aboriginal worldview healing: Inclusion, blending, and bridging. In R. Moodley \& W. West (Eds.), Integrating traditional healing practices into counseling and psychotherapy (pp. 15-25). Thousand Oaks, CA: Sage.

Rosati, J., Carroll, D. and Coate, R. (1990). A critical assessment of the power of human needs in world society. In J. Burton \& F. Dukes (Eds.), Conflict; human needs theory (pp. 257-274). London: Macmillan.

Rothman, J. (1997) Resolving identity-based conflict in nations. San Francisco, CA: Jossey-Bass.

Sarpong-Anane, A.B. (2014). Globalization and indigenous conflict management: Experiences from Africa. In A. G. Adebayo, J. J. Benjamin \& B. D. Lundy (Eds.), Indigenous conflict management strategies: Global perspectives (pp. 75-83). United Kingdom: Lexington Books.

Sulemana, M. (2009). Understanding the causes and impacts of conflicts in the Northern Region of Ghana. Ghana Policy Journal, 3, 110-139.

Tonah, S. (2005). Resolving chieftaincy succession disputes and communal conflicts in Ghana: Lessons from Mamprugu - Northern Ghana. Legon Journal of International Affairs, 2(1), pp. 45-57.

Van Halema, V. and Rassul, K. (2013). Local conflict trend analysis: Balkh Province. Kabul: CPAU.

Williams, M.C. (Ed.) (2007). Realism reconsidered: The legacy of hansmorgenthau in international relations. Oxford: Oxford University Press.

Williams, P.D. (2011). The African Union's conflict management capabilities. Unpublished Manuscript.

Woodley, E. (2002). Local and indigenous knowledge as an emergent property of complexity: A case study in the Solomon Islands. Unpublished Master's Thesis, University of Guelph.

Yelyang, A. (2016). Conflict prevention strategies in northern Ghana: A case study of the ethnic conflicts in Kpemale. Journal of Conflict Transformation \& Security, 5(1), 75-94. 
Yin, R.K. (2003). Case study design and research: design and methods (3rd ed.). Thousand Oaks, CA: Sage Publications.

Zartman, I.W. (2000). Introduction: African traditional conflict medicine. In I. W. Zartman (Ed.), Traditional cures for modern conflicts - African Conflict "Medicine" (pp. 1-11). Boulder, CO: Lynne Rienner. 